\title{
PERILAKU PENGUNJUNG ANAK DI TAMAN WISATA EDUKASI SATWA STUDI KASUS: KEBUN BINATANG GEMBIRA LOKA DI YOGYAKARTA
}

\section{Elma Mahfuzhoh}

Program Studi Arsitektur Fakultas Teknik Universitas Muhammadiyah Surakarta e-mail: Elma.Mahfuzhoh@gmail.com

\section{Andika Saputra}

Program Studi Arsitektur Fakultas Teknik Universitas Muhammadiyah Surakarta e-mail: andika.saputra@ums.ac.id

\begin{abstract}
ABSTRAK
Fenomena yang terjadi pada masa kini adalah maraknya anak-anak dijadikan sebagai sasaran utama pembelajaran dalam wisata edukasi, salah satunya objek adalah kebun binatang Gembira Loka di Yogyakarta yang merupakan salah satu sasaran utama pembelajaran wisata edukasi bagi anak-anak. Penelitian ini bertujuan untuk mengidentifikasi perilaku pengunjung anak di Kebun Binatang Gembira Loka serta faktor spasial yang menyebabkan terjadinya perilaku pada pengunjung anak. Koleksi satwa yang beraneka ragam serta tata ruang yang bervariasi di Kebun Binatang Gembira Loka, beragam perilaku dari pengunjung anak dapat diidentifikasi serta diintrepetasikan sesuai dengan karakteristik lingkungan maupun kepribadian anak, meliputi aspek tingkat keaktifan anak, interaksi anak, dan respon anak terhadap lingkungan yang berbeda. Penelitian ini menerapkan metode kualitatif dengan observasi partisipasi pasif sebagai teknik pencarian data. Hasil penelitian menunjukkan bahwa tingkat keaktifan pengunjung anak terjadi di zona-zona awal, serta faktor spasial yang paling mempengaruhi perilaku pengunjung anak adalah tata ruang zonasi secara makro. Penelitian ini juga menemukan tidak berfungsinya pagar pembatas sebagai respon pengujung anak terhadap kondisi lingkungan.
\end{abstract}

KATA KUNCI: perilaku anak, faktor spasial, wisata edukasi anak.

\section{PENDAHULUAN}

Wisata pendidikan yang dikenal dengan istilah educational tourism merupakan pasar baru dalam ranah jasa pariwisata. Hal ini ditengarai timbul dari keinginan wisatawan untuk lebih mengetahui daerah tujuan wisata yang menyebabkan terjadinya pergeseran tren preferensi wisatawan menuju kegiatan minat khusus dengan partisipasi yang lebih intensif di daerah wisata yang dikunjunginya (Purnawan \& Sudana, 2012).

Fenomena tersebut ditindaklanjuti oleh pihak pengelola wisata dengan menjadikan anak-anak sebagai sasaran utama pengunjung dalam wisata edukasi. Keingintahuan anak yang luas tentang berbagai macam hal serta kebutuhan edukasi alternatif secara informal merupakan beberapa faktor tumbuhnya objek wisata edukasi bagi anak.

Salah satu wisata edukasi bagi anak yang dapat menjadi pilihan adalah kebun binatang. Rencana pembangunan kebun binatang baru di Cimpedeuy oleh pemerintah daerah Bandung Barat (Kompas, 2019) menunjukkan bahwa kebun binatang masih menjadi destinasi yang dibutuhkan serta diminati oleh masyarakat. Fauzia Agustini (2010) mengatakan, bahwa salah satu peran dan fungsi sebuah kebun binatang dalam lingkup pendidikan adalah sebagai sarana pengetahuan kepada masyarakat luas mengenai pentingnya konservasi alam dan lingkungan melalui peragaan maupun pertunjukan satwa.

Gembira Loka di Yogyakarta yang merupakan salah satu kebun binatang di Indonesia memiliki fungsi dan tujuan sebagaimana disampaikan oleh Tirtodiprojo (2008: 44) sebagai berikut:

Konsep Gembira Loka yang naturalistik merupakan wadah kegiatan rekreasi alami yang fungsi dan tujuannya sebagai tempat rekreasi, konservasi, penelitian dan edukasi, perkembangan ilmu zoology dan botani di Indonesia dan kesadaran masyarakat dalam merawat, menjaga dan melindungi flora dan fauna.

Gembira Loka bukan hanya sebagai lembaga konservasi dan paru-paru kota Jogja, namun juga merupakan objek wisata edukasi. Dengan persentase 60-70\% kunjungan berusia anak-anak, Gembira Loka menyediakan berbagai fasilitas untuk mewujudkan tempat wisata ramah anak. Untuk itu kebun binatang Gembira Loka menjadi anggota APSAI (Asosiasi Perusahaan Sahabat Anak Indonesia) dan bekerjasama dengan DPPMPA (Dinas Pemberdayaan Perempuan dan Perlindungan Anak). 
Keberagaman aktifitas yang terjadi serta beragamnya satwa di Kebun Binatang Gembira Loka, ragam perilaku dari pengunjung anak akan dapat diidentifikasikan serta diintepretasikan sesuai dengan karakteristik lingkungan maupun kepribadian individu masing-masing anak meliputi aspek tingkat keaktifan terhadap kondisi lingkungan dan satwa, interaksi, dan sikap anak dalam menanggapi karakter lingkungan yang berbeda.

Berdasarkan permasalahan di atas, peneliti ini menetapkan rumusan masalah sebagai berikut :

1. Seperti apa perilaku pengunjung anak di Kebun Binatang Gembira Loka?

2. Apa saja faktor spasial yang mempengaruhi perilaku anak di Kebun Binatang Gembira Loka?

Dengan rumusan masalah tersebut, tujuan dilakukannya penelitian ini adalah sebagai berikut:

1. Mengidentifikasi perilaku pengunjung anak di Kebun Binatang Gembira Loka.

2. Mengidentifikasi faktor-faktor spasial yang mempengaruhi perilaku pengunjung anak.

Penelitian ini bermanfaat dapat membantu peneliti lain dalam mengkaji perilaku anak di ruang publik. Selain itu, penelitian ini juga dapat menjadi salah satu sudut pandang bagi pihak pengelola untuk mengembangkan kawasan Gembira Loka yang sampai akhir penelitian ini memang memiliki rencana pengembangan kawasan wisata. Penelitian ini pun dapat menjadi salah satu sumber pedoman dalam perancangan desain ruang publik maupun kawasan wisata edukasi satwa yang ramah anak.

Penelitian ini dilandasi teori perilaku anak untuk digunakan sebagai pedoman dalam melakukan pengamatan. Campos (dalam Nurmalitasari, 2015) mengatakan bahwa perilaku merupakan ekspresi dari emosi nyaman atau tidaknya keadaan psikologis atau interaksi yang dialami seseorang. Emosi yang dimaksud dapat berupa rasa senang, marah, takut, dan sebagainya.

Anak-anak memiliki karakteristik emosi yang berbeda dengan orang dewasa. Pada umumnya, keterbatasan daya nalar pada anak menyebabkan anak sulit untuk mengontrol emosi, sehingga emosi anak dapat terbaca dengan jelas secara jujur dari perilakunya. Nurmalitasari (2015) menyebutkan karakteristik emosi pada anak antara lain (1) berlangsung singkat dan berakhir tiba-tiba; (2) terlihat lebih hebat atau kuat; (3) bersifat sementara atau dangkal; (4) lebih sering terjadi; (5) dapat diketahui dengan jelas dari perilakunya, dan (6) reaksi mencerminkan individualitas.

Di dalam Handbook for Public Playground Safety (2010) menyebutkan, bahwa dalam mendesain ruang yang ramah anak terdapat beberapa faktor kunci yang harus diperhatika, meliputi (1) aksesibilitas, (2) perbedaan usia anak, (3) aktifitas yang bersinggungan, (4) garis pembatas area permainan, (5) penanda atau penunjuk permainan, dan (6) pengawas.

\section{METODE PENELITIAN}

Penelitian menggunakan metode penelitian kualitatif. Lokus penelitian adalah Kebun Binatang Gembira Loka yang dibatasi sesuai variabel-variabel lokus. Berdasarkan wawancara yang dilakukan dengan pihak pengelola, zonasi jenis satwa yang diberlakukan di Gembira Loka meliputi Bird Park, Reptiles \& Amphibians Park, Aquarium, Scratch Zone, dan Primata. Satwa-satwa selain zonasi tersebut ditempatkan tanpa pengelompokan spesifik.

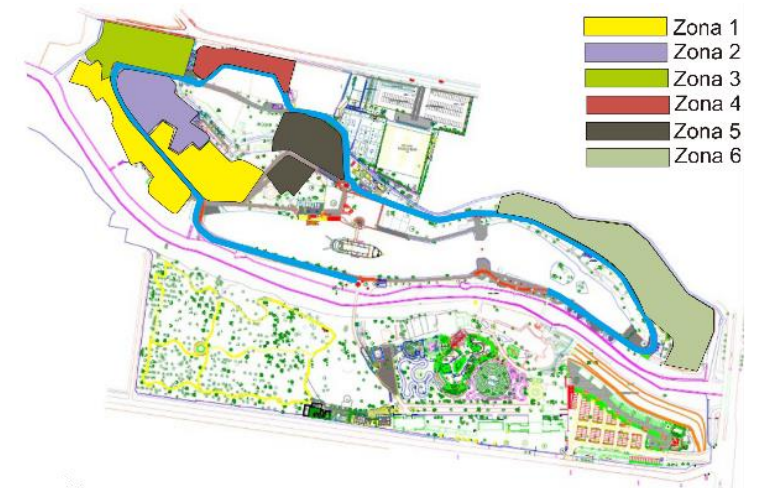

Gambar 1. Site Plan zonasi lokus penelitian (Sumber : dokumen penulis, 2019)

Peneliti menetapkan variabel lokus dengan menggunakan penyebutan variabel taman edukasi satwa. Adapun variabel lokus dalam penelitian ini adalah sebagai berikut:

1. Makro. Bagian inimeliputi tata letak sirkulasi dari keseluruhan wilayah Gembira Loka, seperti tertera pada Tabel 1.

Tabel 1. Kode Zonasi pada Zonasi Makro

\begin{tabular}{cl}
\hline $\begin{array}{c}\text { Kode } \\
\text { Zonasi }\end{array}$ & \multicolumn{1}{c}{ Satwa yang terletak pada zonasi } \\
\hline \hline Zona 1 & $\begin{array}{l}\text { Gajah, Orang Utan, Simpanse, Kolam } \\
\text { Arapaima, Aquarium, Buaya, Wallaby, Kuda Nil } \\
\text { Kerdil, Babi Hutan, Binturong, Kancil, Burung } \\
\text { Kasuaridan Harimau }\end{array}$ \\
\hline \hline Zona 2 & Zona Reptiles \& Amphibian Park. \\
\hline \hline Zona 3 & Bird Park. \\
\hline \hline Zona 4 & Scratch Zone. \\
\hline \hline Zona 5 & $\begin{array}{l}\text { Primata dan Termasuk juga area Presentasi } \\
\text { Edukasi Satwa Mamalia (PES Mamalia) }\end{array}$ \\
\hline \hline Zona 6 & $\begin{array}{l}\text { Watusi, Nilgai, Burung Onta, Kasuari, Tapir } \\
\text { Asia, Tapir Brazil, Onta, dan Kuda Nil }\end{array}$ \\
\hline
\end{tabular}

Pada aspek sirkulasi makro, peneliti membagi menjadi dua jenis sirkulasi, yakni sirkulasi linear meliputi jalur utama yang melewati keseluruhan zona, serta sirkulasi tidak linear yang tidak mengikuti jalur sirkulasi utama serta tidak melewati keseluruhan zona lokus penelitian. 
2) Meso. Bagian ini meliputi tata letak kandang dan sirkulasi dari tiap-tiap wilayah zonasi seperti pada Tabel 2 dan 3.

Tabel 2. Pengelompokan berdasarkan Tata Letak Kandang Tata Letak Kandang

\begin{tabular}{cc}
\multicolumn{2}{c}{ Tata Letak Kandang } \\
\hline Berkelompok & Memanjang \\
\hline 1. Area 2 & 1. Area 1 \\
\hline 2. Area 3 & 2. Area 4 \\
\hline & 3. Area 5 \\
\hline & 4. Area 6 \\
\hline
\end{tabular}

Tabel 3. Pengelompokan Berdasarkan Sirkulasi Zonasi

\begin{tabular}{ll}
\hline \multicolumn{2}{c}{ Sirkulasi pada Zonasi } \\
\hline Sirkulasi Linear & Sirkulasi Spiral \\
\hline 1. Area 1 & 1. Area 2 \\
\hline 2. Area 4 & 2. Area 3 \\
\hline 3. Area 5 & \\
\hline 4. Area 6 & \\
\hline
\end{tabular}

3) Mikro. Bagian mikro meliputi ruang lingkup dari kandang dengan variabel 1) tipe kandang; 2) unsur pengaman, serta 3) jarak satwa, seperti tertera pada Tabel 4, 5 dan 6 .

Tabel 4. Pengelompokan Berdasarkan

\begin{tabular}{cc}
\multicolumn{2}{c}{ Tipe Kandang } \\
\hline \multicolumn{2}{c}{ Tipe Kandang } \\
\hline Terbuka & Tertutup \\
\hline 1. Zona 1 & 1. Zona 2 \\
\hline 2. Zona 5 & 2. Zona 3 \\
\hline 3. Zona 6 & 3. Zona 4 \\
\hline
\end{tabular}

Tabel 5. Pengelompokan Berdasarkan Tinggi Pembatas

\begin{tabular}{|c|c|}
\hline \multicolumn{2}{|c|}{ Tinggi Pembatas } \\
\hline \multicolumn{2}{|c|}{ Unsur Pengaman } \\
\hline $\begin{array}{c}\text { Pembatas Lebih } \\
\text { Tinggi }\end{array}$ & $\begin{array}{c}\text { Pembatas Lebih } \\
\text { Rendah }\end{array}$ \\
\hline $\begin{array}{l}\text { Kandang Gajah } \\
\text { (Zona 1) }\end{array}$ & $\begin{array}{c}\text { Kandang Orang } \\
\text { Utan (Zona 1) }\end{array}$ \\
\hline
\end{tabular}

Tabel 6. Pengelompokan Berdasarkan Jarak Satwa

\begin{tabular}{cc}
\multicolumn{2}{c}{ Jarak Satwa } \\
\hline $\begin{array}{c}\text { Jarak Satwa dari Pengunjung dari } \\
\text { Pengunjung }\end{array}$ & $\begin{array}{c}\text { Dekat dengan } \\
\text { pengunjung }\end{array}$ \\
\hline 1. Zona 1 & 1. Zona 2 \\
\hline 2. Zona 4 & 2. Zona 3 \\
\hline 3. Zona 5 & \\
\hline 4. Area 6 \\
\hline
\end{tabular}

Fokus penelitian adalah perilaku pengunjung anak pada titik lokasi yang telah ditentukan. Perilaku yang diamati meliputi perilaku verbal dan non verbal yang menunjukkan respon terhadap setting lingkungan pada masing-masing zonasi.

Teknik pengumpulan data dilakukan dengan dua cara, yakni observasi dan wawancara. Pada penelitian ini digunakan metode observasi partisipasi pasif yang memungkinkan peneliti untuk mengamati perilaku pengunjung anak tanpa mengganggu proses kegiatannya. Adapun responden yang dilibatkan dalam penelitian merupakan pengunjung anak dengan kriteria sebagai berikut:

1) Responden merupakan pengunjung anak

2) Responden berusia 1-12 tahun

3) Responden tidak sedang duduk dalam stroller untuk memudahkan pengamatan

Penelitian ini melibatkan 8 responden yang terdiri dari 4 responden individu dan 4 responden kelompok dengan profil responden sebagai berikut:

Tabel 7. Data Responden

\begin{tabular}{cccc}
\hline No. & Responden & Jenis Responden & Gender \\
\hline 1 & Responden 1 & Individu & $\mathrm{L}$ \\
\hline 2 & Responden 2 & Individu & $\mathrm{P}$ \\
\hline 3 & Responden 3 & Individu & $\mathrm{P}$ \\
\hline 4 & Responden 4 & Individu & $\mathrm{L}$ \\
\hline 5 & Responden 5 & Berkelompok & $\mathrm{L}$ \\
\hline 6 & Responden 6 & Berkelompok & $\mathrm{P}$ \\
\hline 7 & Responden 7 & Berkelompok & $\mathrm{L}$ \\
\hline \hline 8 & Responden 8 & Berkelompok & $\mathrm{P}$ \\
\hline
\end{tabular}

Dalam melakukan observasi, peneliti menggunakan behavioral mapping dengan pemetaan perilaku berdasarkan pelaku (person centered mapping) untuk memudahkan pemetaan data. Pemetaan berdasarkan pelaku atau responden ini mensyaratkan peneliti harus mengikuti kegiatan tiap responden untuk dapat mengumpulkan data. Data yang dihasilkan berupa sketsa serta catatan narasi yang kemudian ditabulasi ke dalam kelompok data serta dijabarkan berdasarkan variabel lokus yang telah ditentukan.

Metode wawancara semi terstruktur digunakan untuk mewawancarai pihak pengelola dikarenakan memiliki fleksibilitas bagi pewawancara untuk menyesuaikan dengan kondisi responden yang akan diwawancarai, sehingga wawancara dapat berlangsung lebih luwes. Wawancara dilakukan dengan Bapak Ibnu dari bagian pelayanan yang juga bertanggungjawab atas pengembangan konsep ramah anak pada Kebun Binatang Gembira Loka.

Penyajian data dilakukan dalam 2 model, yakni model kecenderungan dan model narasi perilaku dikarenakan di beberapa zonasi tidak dapat dijelaskan melalui model kecenderungan, sehingga perilaku yang dilakukan oleh responden harus didiskripsikan melalui narasi singkat. Berdasarkan data penelitian terbentuk dua tipe kecenderungan, yakni perilaku aktif dan perilaku pasif. Perilaku aktif ditandai dengan dilakukannya perilaku yang bersifat positif maupun negatif pada satwa maupun lingkungan sekitarnya. Kelompok perilaku aktif yang ditemui secara umum adalah sebagai berikut: 
Tabel 8. Kelompok Perilaku Aktif

\begin{tabular}{|c|c|}
\hline Positif & Negatif \\
\hline $\begin{array}{l}\text { 1. Berinteraksi dengan } \\
\text { satwa }\end{array}$ & $\begin{array}{l}\text { 1. Menjauhi satwa } \\
\text { yang ditakuti }\end{array}$ \\
\hline 2. Berekspresi gembira & 2. Takut \\
\hline 3. Bersemangat & 3. Berteriak \\
\hline \multirow[t]{2}{*}{ 4. Aktif bergerak } & 4. Bersikap tidak suka \\
\hline & 5. Menangis \\
\hline
\end{tabular}

Perilaku responden dikategorikan sebagai perilaku pasif apabila tidak dilakukan perilaku maupun tidak terdapatnya ekspresi dari responden. Contoh perilaku pasif yang ditemui adalah kecenderungan untuk hanya berjalan terus tanpa tertarik untuk mengamati satwa. Selain itu termasuk perilaku negatif adalah responden teralihkan perhatiannya pada objek yang tidak termasuk sebagai elemen satwa maupun elemen kandang.

\section{HASIL PENELITIAN}

\section{Zonasi Makro}

Pada zonasi makro, responden menunjukkan tipe kecenderungan aktif dan pasif sebagaimana Tabel 9:

Tabel 9.Kecenderungan Perilaku pada Zonasi Makro

\begin{tabular}{|c|c|c|c|c|c|c|}
\hline \multicolumn{7}{|c|}{ Kecenderungan Perilaku } \\
\hline Zonasi & 1 & 2 & 3 & 4 & 5 & 6 \\
\hline \multicolumn{7}{|l|}{ Responden 1} \\
\hline \multicolumn{7}{|l|}{ Responden 2} \\
\hline \multicolumn{7}{|l|}{ Responden 3} \\
\hline \multicolumn{7}{|l|}{ Responden 4} \\
\hline \multicolumn{7}{|l|}{ Responden 5} \\
\hline \multicolumn{7}{|l|}{ Responden 6} \\
\hline \multicolumn{7}{|l|}{ Responden 7} \\
\hline \multicolumn{7}{|l|}{ Responden 8} \\
\hline \multicolumn{7}{|l|}{ Keterangan : } \\
\hline Aktif & Pasif & - & lak & elal & Area & \\
\hline
\end{tabular}

Di zona 1 dan 2, seluruh responden menunjukkan perilaku aktif. Orang utan menarik perhatian beberapa responden yang membuat responden mencoba menirukan suaranya. Pada zona 2 para responden menunjukkan perilaku paling antusias dengan aktif berlari serta mengidentifikasi satwa yang ada. Tidak jarang membuat keributan saat melihat satwa yang disukai.

Di zona 3, responden menunjukkan perilaku aktif memasuki dome yang memungkinkan terjadinya interaksi langsung dengan satwa burung. Salah satu interaksi yang terbentuk sebagai bentuk antusiasme responden adalah menirukan suara burung. Selain perilaku aktif, perilaku pasif didapati pada beberapa responden yang ditunjukkan dengan berjalan cepat serta tidak banyak melakukan pengamatan.

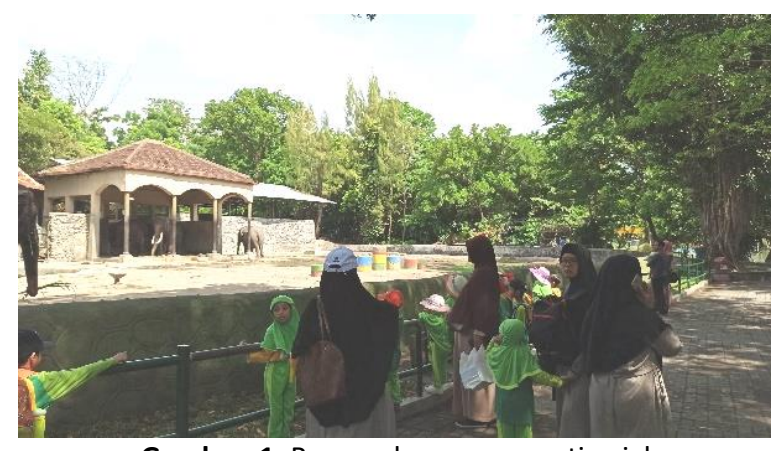

Gambar 1. Responden mengamati gajah (Sumber : Dokumentasi penulis, 2019)

Di zona 4, sebagian besar responden melakukan perilaku pasif dengan berjalan cepat tanpa mengamati satwa yang ada. Responden juga teralihkan fokusnya pada makanan ringan maupun teman-teman sebaya. Responden yang menunjukkan perilaku aktif mengamati dengan mencari-cari satwa yang bersembunyi serta banyak bicara dengan teman-temannya.

Di zona 5, responden melakukan perilaku aktif di area Presentasi Edukasi Satwa (PES). Mulai di zona 5 banyak responden memilih jalur yang berbeda, sehingga responden tersebut tidak melalui keseluruhan zona di Kebun Binatang Gembira Loka.

Di zona 6, keseluruhan responden tidak menunjukkan perilaku aktif. Beberapa dari responden memilih untuk menaiki taring (Transportasi Keliling) sehingga tidak fokus mengamati satwa.

\section{Sirkulasi Makro}

Pada variabel sirkulasi makro, ditemukan 2 jenis sirkulasi, yakni sirkulasi linear dan tidak linear. Sirkulasi tergolong tidak linear karena responden tidak melewati jalur utama. Terdapat pula beberapa jalur bercabang, seperti jalan pintas langsung ke area 4 sehingga pengunjung tidak harus memasuki area 3 (lihat Tabel 10).

Responden 1, 2, dan 3 yang tergabung dalam rombongan wisata yang sama memilih untuk mengikuti sirkulasi utama. Hal ini terjadi karena pihak rombongan menggunakan pemandu wisata yang disediakan pengelola.

Responden 4 yang merupakan pengunjung individu melakukan perjalanan wisata dengan mengikuti jalur utama, tetapi pada saat berada di area 5 responden memilih berjalan kembali ke area 1 untuk keluar melalui rute masuk kebun binatang.

Responden 5 dan 6 yang merupakan rekan satu rombongan diberi instruksi oleh pendamping mereka untuk keluar melalui pintu Barat yang terletak sebelum area 5 .

Responden 6 dan 7 melakukan perjalanan sesuai jalur utama. Berbeda degan responden-responden sebelumnya, responden ini memilih untuk mengikuti sirkulasi area 1 hingga selesai, dan di ujung area 1 di 
mana terdapat kandang harimau Sumatra, responden menyadari pintu masuk ke area 2 melalui jalan setelah aquarium, sehingga rombongan berbalik untuk memasuki area 2.

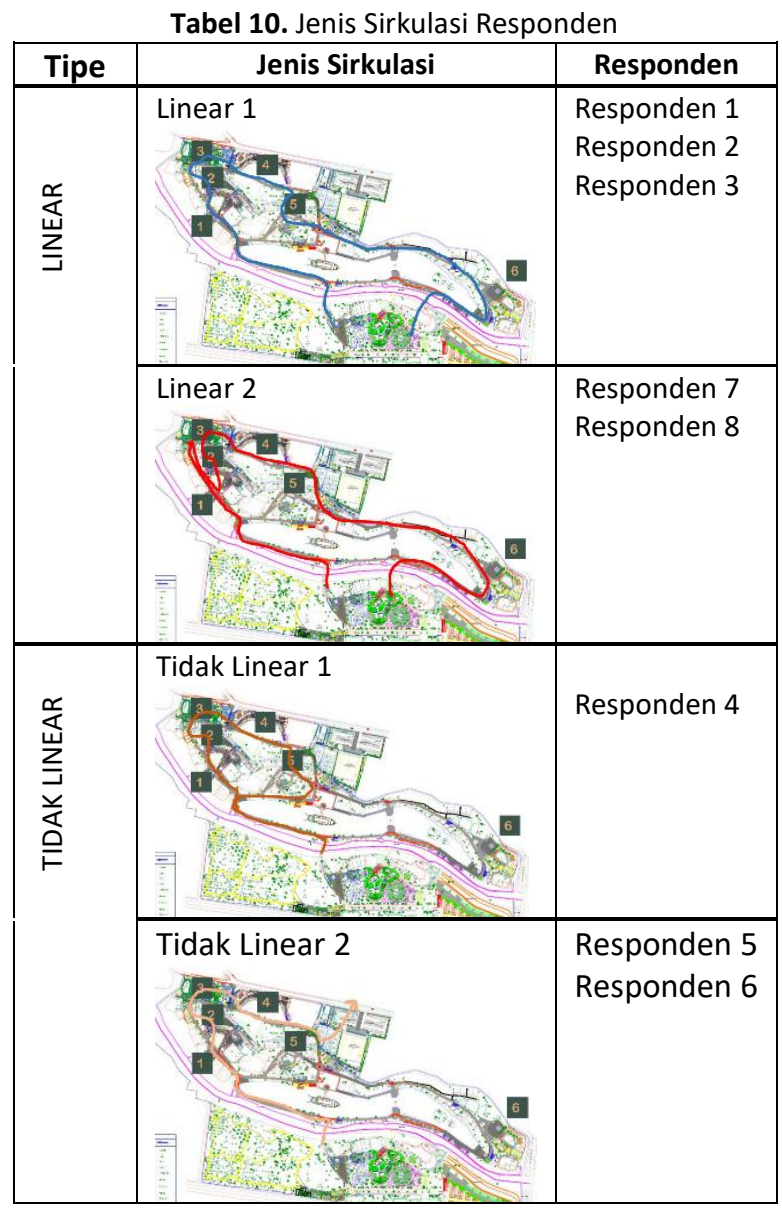

\section{Tata Letak Kandang}

Pengamatan pada variabel tata letak kandang terbagi menjadi 2 bentuk amatan, yakni responden mengunjungi salah satu kandang atau responden menjelajahi seluruh kandang.

Tabel 11. Kecenderungan Perilaku pada Tata Letak Kandang dalam Zonasi

\begin{tabular}{|c|c|c|}
\hline \multicolumn{3}{|c|}{ Kecenderungan Perilaku } \\
\hline $\begin{array}{l}\text { Tata Letak } \\
\text { Kandang }\end{array}$ & Berkelompok & Memanjang \\
\hline Responden 1 & & \\
\hline Responden 2 & & \\
\hline Responden 3 & & \\
\hline Responden 4 & & \\
\hline Responden 5 & & \\
\hline Responden 6 & & \\
\hline Responden 7 & & \\
\hline Responden 8 & & \\
\hline Keterangan : & $\begin{array}{l}\text { Mengunjungi sa } \\
\text { Menielaiahi sem }\end{array}$ & $\begin{array}{l}\text { atu kandang } \\
\text { andang }\end{array}$ \\
\hline
\end{tabular}

Responden yang hanya mengunjungi salah satu kandang diinterpretasikan hanya tertarik pada salah satu kandang saja, sedangkan responden yang menjelajahi seluruh kandang diinterpretrasikan bahwa responden tertarik dengan seluruh satwa sehingga mengamati satu persatu kandang dengan melewati sirkulasi yang tersedia.

\section{Sirkulasi Meso}

Pada hasil observasi, ditemukan beberapa perilaku terkait keaktifan responden dalam berinteraksi sebagaimana Tabel 12.

Tabel 12. Kecenderungan Perilaku pada Sirkulasi Zonasi

\begin{tabular}{|c|c|c|}
\hline \multicolumn{3}{|c|}{ Kecenderungan Perilaku } \\
\hline Tipe Sirkulasi & Linear & Spiral \\
\hline Responden 1 & & \\
\hline Responden 2 & & \\
\hline Responden 3 & & \\
\hline Responden 4 & & \\
\hline Responden 5 & & \\
\hline Responden 6 & & \\
\hline Responden 7 & & \\
\hline Responden 8 & & \\
\hline
\end{tabular}

\section{Tipe Kandang}

Perilaku aktif pada variabel tipe kandang terbuka banyak ditunjukkan dengan meneriakkan nama dari satwa maupun menirukan suara dari satwa yang sedang diamati, dengan tujuan untuk mencari perhatian dari satwa-satwa tersebut. Sementara perilaku aktif pada tipe kandang tertutup ditunjukkan dengan mengetuk kaca yang digunakan sebagai penutup kandang.

Tabel 13. Kecenderungan Perilaku pada Tipe Kandang

\begin{tabular}{ll}
\hline \multicolumn{2}{c}{ Kecenderungan Perilaku } \\
\hline \hline Tipe Kandang & Terbuka \\
\hline \hline Responden 1 & \\
\hline Responden 2 & \\
\hline Responden 3 & \\
\hline Responden 4 & \\
\hline Responden 5 & \\
\hline \hline Responden 6 & \\
\hline Responden 7 & \\
\hline Responden 8 & \\
\hline Keterangan : $\quad$ Aktif $\quad$ Pasif \\
\hline
\end{tabular}

\section{Unsur Pengaman}

Dari observasi yang dilakukan ditemukan bahwa responden menanggapi secara berbeda setiap profil pembatas kandang sebagaimana dijelaskan dalam Tabel 14.

Tabel 14. Perilaku Berdasarkan Tipe Pembatas

\begin{tabular}{lclc}
\hline & \multicolumn{3}{c}{ Perilaku yang terbentuk } \\
\cline { 2 - 4 } No & $\begin{array}{c}\text { Tipe } \\
\text { Ketinggian } \\
\text { Pembatas }\end{array}$ & Pembatas tinggi & $\begin{array}{c}\text { Pembatas } \\
\text { lebih } \\
\text { rendah }\end{array}$ \\
\hline 1 & Responden 1 & $\begin{array}{l}\text { Pada pembatas } \\
\text { yang berlubang }\end{array}$ & - \\
& & \begin{tabular}{l} 
menengok dari \\
\hline
\end{tabular}
\end{tabular}




\begin{tabular}{|c|c|c|c|}
\hline \multirow[b]{2}{*}{ No } & \multicolumn{3}{|c|}{ Perilaku yang terbentuk } \\
\hline & $\begin{array}{c}\text { Tipe } \\
\text { Ketinggian } \\
\text { Pembatas } \\
\end{array}$ & Pembatas tinggi & $\begin{array}{c}\text { Pembatas } \\
\text { lebih } \\
\text { rendah } \\
\end{array}$ \\
\hline & & celah lubang & \\
\hline 2 & Responden 2 & - & - \\
\hline 3 & Responden 3 & $\begin{array}{l}\text { Meraih } \\
\text { pegangan } \\
\text { pembatas } \\
\end{array}$ & - \\
\hline 4 & Responden 4 & - & - \\
\hline 5 & Responden 5 & - & $\begin{array}{l}\text { Duduk di } \\
\text { pembatas }\end{array}$ \\
\hline 6 & Responden 6 & - & $\begin{array}{l}\text { Duduk di } \\
\text { pembatas }\end{array}$ \\
\hline 7 & Responden 7 & $\begin{array}{l}\text { Memanjat } \\
\text { pembatas yang } \\
\text { berlubang }\end{array}$ & - \\
\hline 8 & Responden 8 & $\begin{array}{l}\text { Merasa } \\
\text { penasaran } \\
\text { kemudian } \\
\text { berjinjit }\end{array}$ & - \\
\hline
\end{tabular}

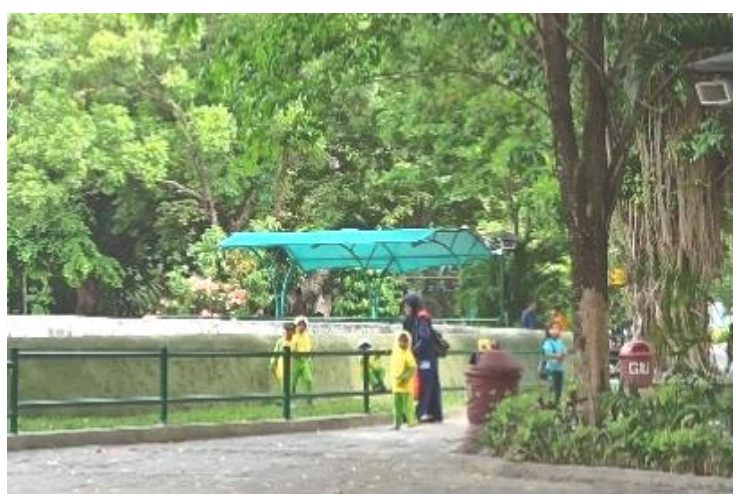

Gambar 3. Responden melewati pagar pembatas (Sumber: Dokumentasi penulis, 2019)

\section{Jarak Satwa Dengan Pengunjung}

Hasil observasi menunjukkan bahwa setiap responden memiliki preferensi masing-masing dalam menanggapi satwa. Tipe perilaku yang dilakukan responden dalam variabel ini terdiri dari perilaku aktif-negatif.

Tabel 15. Kecenderungan Perilaku terhadap Jarak Satwa

\begin{tabular}{|c|c|c|c|}
\hline \multicolumn{4}{|c|}{ Kecenderungan Perilaku } \\
\hline No & Jarak Satwa & $\begin{array}{c}\text { Dekat dengan } \\
\text { Responden }\end{array}$ & $\begin{array}{c}\text { Jauh dari } \\
\text { Responden }\end{array}$ \\
\hline 1 & Responden 1 & & \\
\hline 2 & Responden 2 & & \\
\hline 3 & Responden 3 & & \\
\hline 4 & Responden 4 & & \\
\hline 5 & Responden 5 & & \\
\hline 6 & Responden 6 & & \\
\hline 7 & Responden 7 & & \\
\hline 8 & Responden 8 & & \\
\hline Kete & gan : __ Akti & ositif & satif \\
\hline
\end{tabular}

Pada posisi jarak satwa yang dekat dengan responden, responden cenderung aktif dengan salah satu responden menunjukkan respon perilaku negatif dengan menangis kencang dan berteriak ketakutan saat didekati satwa. Pada satwa yang jaraknya jauh, responden juga menunjukkan kecenderungan untuk aktif seperti dengan memanggil satwa tersebut.

\section{Faktor Spasial yang Mempengaruhi Perilaku Layout zonasi}

Layout zonasi menjadi salah satu faktor karena bagi pengunjung untuk menentukan zonasi yang akan dijelajahi maupun tidak dikunjunginya mengingat area kebun binatang Gembira Loka sangat luas. Seperti di zona 1 di mana responden secara keseluruhan berperilaku aktif dikarenakan salah satunya dipengaruhi penataan kandang yang tidak terlalu padat. Dengan menampilkan hewan berukuran besar di area depan kebun binatang menjadikan responden merasa antusias.

Zona 6 menjadi area di mana hampir semua responden bersikap pasif. Faktor paling besar yang menyebabkannya adalah dikarenakan zona 6 merupakan area terjauh jika melalui sirkulasi utama kebun binatang. Di area 6 responden telah merasa lelah akibat berjalan jauh. Responden yang usianya masih anak-anak memiliki keterbatasan stamina jika dibandingkan pengunjung dewasa, sehingga track memutar dinilai kurang bersahabat dengan kondisi anak-anak.

\section{Layout Sirkulasi}

Para responden yang melakukan kunjungan wisata dengan menggunakan sirkulasi linear dikarenakan memiliki kondisi jalan yang bagus dengan rute yang jelas. Salah satu faktor yang menyebabkan area primata tidak banyak didatangi oleh pengunjung adalah dikarenakan jalur sirkulasi yang sempit. Sementara itu responden yang melewati jalur sirkulasi di luar jalur utama dikarenakan ingin melalui rute yang berbeda dengan pengunjung pada umumnya.

\section{Penempatan Papan Informasi}

Responden 7 dan 8 mengalami kebingungan untuk menemukan gerbang masuk area 2 dikarenakan kurangnya informasi dan penanda lokasi.

\section{Bentuk Sirkulasi Pada Setiap Zonasi}

Zona 2 dengan bentuk sirkulasi spiral memutar menyebabkan responden aktif bergerak, tetapi menyebabkan respoden kurang berinteraksi dengan satwa.

\section{Tata Letak Kandang}


Pada tata letak kandang yang mengelompok, responden membutuhkan waktu untuk memilah informasi visual. Responden rata-rata akan mendatangi area kandang yang menarik perhatiannya.

Pada tata letak kandang yang memanjang, responden memiliki sudut pandang yang lebih lebar sehingga juga membutuhkan waktu untuk melakukan pemilahan informasi visual. Perbedaan hasil yang mencolok adalah penataan kandang yang memanjang menyebabkan responden merasa memiliki waktu untuk meyisir sepanjang seluruh kandang.

\section{Posisi dan Lebar Jalan}

Zona 4 berupa Scratch Zone dengan lebar jalur sirkulasi yang sempit menyebabkan responden berperilaku kurang aktif. Selain itu banyak pengunjung menghindari untuk berhenti di area ini dikarenakan takut akan menghambat perjalanan pengunjung lainnya.

Pada sirkulasi zonasi, responden cenderung aktif dengan bentuk sirkulasi linear dan penempatan kandang di sepanjang jalur sirkulasi tersebut dikarenakan responden merasa memiliki waktu untuk menyisir seluruh kandang yang ditampilkan. Selain itu sirkulasi linear kecuali di zona 4 dan 5 memiliki dimensi yang lebar, sehingga pengunjung anak merasa lebih leluasa untuk berjalan maupun berlari.

\section{Konsep Ruang}

Di zona 3 yang menampilkan berbagai jenis burung menunjukkan tingkat perilaku aktif yang tinggi dari responden dikarenakan terdapat dome yang memiliki daya tarik bagi responden untuk berinteraksi secara langsung dengan satwa yang ditampilkan.

Zona 5 yang posisinya di area tengah kebun binatang Gembira Loka mampu membuat responden kembali aktif dikarenakan di area tersebut terdapat Presentasi Edukasi Satwa Mamalia (PES Mamalia). Di PES Mamalia responden disuguhi pengenalan satwa yang menarik, sehingga responden merasa tertarik untuk kembali berkegiatan.

\section{Tampilan Kandang}

Responden memiliki kecenderungan untuk lebih aktif di area kandang yang tertutup disebabkan responden merasa lebih dekat dengan satwa karena dibatasi dengan dinding kaca.

Tampilan kandang dengan suasana cenderung gelap menyebabkan responden tidak tertarik, sehingga tidak mau melewati zona tersebut, seperti area primata yang berada di jalur sirkulasi menuju PES Mamalia tidak dikunjungi oleh responden, selain dikarenakan area tersebut tidak dilengkapi identitas area yang menarik perhatian responden.

\section{Pagar Pembatas}

Responden memiliki tanggapan yang berbedabeda ketika dihadapkan pada bentuk pagar pembatas yang bervariasi. Bentuk pagar pembatas yang cukup tinggi menyebabkan responden merasa ingin tahu apa yang berada dibalik pembatas tinggi, sehingga mendorong responden untuk berperilaku memanjat maupun berjinjit.

Untuk bentuk pagar pembatas yang berlubang, responden merasa memiliki akses untuk dapat melihat apa yang berada di balik pembatas, sehingga mendorong responden untuk melewati pagar pembatas, terutama jika tidak sedang diawasi. Perilaku tersebut tergolong perilaku berbahaya di area kebun binatang.

Sementara bagi responden yang memiliki postur tubuh tinggi cenderung menunjukkan perilaku duduk di area pembatas yang rendah.

\section{PEMBAHASAN}

Dalam lingkup makro, variabel layout zonasi dan pola sirkulasi makro paling berpengaruh terhadap tingkat keaktifan responden. Penempatan zonasi pada jarak yang cukup jauh, seperti area 6 menyebabkan responden berperilaku pasif. Jalur sirkulasi utama yang terbilang jauh juga menyebabkan perilaku untuk tidak mengikuti jalur sirkulasi linear. Pada dasarnya pengelola memberikan kebebasan kepada para pengunjung untuk melalui sirkulasi yang diinginkan, tetapi dalam penerapannya justru dengan sirkulasi yang bercabang menyebabkan beberapa responden bersikap pasif serta melewatkan zona yang berada di akhir perjalanan.

Dalam lingkup meso, data menunjukkan beberapa responden cenderung dapat mengikuti perjalanan dan berinteraksi dengan satwa ketika mereka diberi jangkauan pandangan yang luas dengan penataan kandang yang memanjang, seperti di zona 1. Akan tetapi, jangkauan yang luas juga mendorong pengunjung anak-anak untuk hanya terpaku pada salah satu titik dengan melewatkan titik lainnya.

Pada lingkup mikro, variabel tipe kandang dan jarak satwa berpengaruh terhadap keaktifan perilaku responden. Responden yang merasa takut untuk berinteraksi dalam jarak dekat dengan satwa akan lebih nyaman berada di zonasi dengan bentuk kandang yang tertutup.

Hal lain pada lingkup mikro yang penting untuk diperhatikan adalah variabel unsur pengaman. Ketinggian pembatas yang seharusnya ditujukan untuk memenuhi aspek keamanan, justru disalahgunakan oleh responden dengan berperilaku duduk di pembatas yang pendek dikarenakan mempersepsikannya sebagai fasilitas tempat duduk. Begitu juga bagi responden yang melewati pagar pembatas mempersepsikan bahwa pagar pembatas 
merupakan area bermain. Kurangnya pengawasan serta informasi di area-area tersebut menjadi salah satu faktor responden berperilaku yang tergolong membahayakan keselamatan dirinya.

\section{KESIMPULAN}

Penelitian ini menunjukkan bahwa responden menunjukkan kecenderungan respon perilaku paling aktif di zona awal dan perilaku pasif di zona akhir, serta menunjukkan respon perilaku ekstrim pada variabel pagar pembatas. Faktor spasial yang paling dominan mempengaruhi perilaku responden adalah layout zonasi dan variasi bentuk pagar pembatas.

\section{UCAPAN TERIMAKASIH}

Peneliti mengucapkan terimakasih kepada pihak pengelola Kebun Binatang Gembira Loka yang telah memberikan izin serta bersedia untuk memberikan data-data penelitian yang dibutuhkan.

Tidak lupa juga peneliti mengucapkan terimakasih kepada pihak universitas, meliputi pihak program studi dan dosen pembimbing yang telah memberikan pembimbingan, perizinan, serta membantu peneliti untuk menyelesaikan penelitian.

\section{DAFTAR PUSTAKA}

Agustini, Fauzia. (2010). Pengelolaan Pariwisata Kebun Binatang Medan (KBM) Ditinjau Dari Persepsi Para Wisatawan Pengunjung, Inovasi Jurnal Politik Dan Kebijakan Vol 7 Issue 2

Nurmalitasari, F. (2015). Perkembangan Sosial Emosi Pada Anak Usia Prasekolah. Buletin Psikologi, Volume 23, No. 2, Desember 2015: 103 - 111 ISSN: 0854-7108, Fakultas Psikologi Universitas Gadjah Mada, Https://Doi.Org/10.22146/Bpsi. 10567

Purnawan, Ni Luh Ramaswati, I Putu Sudana, (2012). Wisata Edukasi Budaya Bali, Jurnal Ngayah Vol 3 Issue 4

Tirtodiprojo Dkk. (2008). Panduan Satwa. Yogyakarta: Kebun Raya Dan Kebun Binatang Gembira Loka 